\title{
Effect of Seed Bed and Integrated Nitrogen Management on Growth and Yield of Sorghum (Sorghum bicolor L.)
}

\author{
Ashwani Singh* and Rajesh Singh
}

Department of Agronomy, SHUATS, Sam Higginbottom University of Agriculture, Technology and Sciences (Formerly Allahabad Agricultural Institute), Allahabad-21100, Uttar Pradesh, India

\author{
*Corresponding author
}

\author{
A B S T R A C T
}

\begin{tabular}{|l|}
\hline Key w or d s \\
$\begin{array}{l}\text { Sorghum, Seed bed, } \\
\text { Integrated nitrogen } \\
\text { management, } \\
\text { Growth and yield. }\end{array}$ \\
\hline Article Info \\
\hline $\begin{array}{l}\text { Accepted: } \\
07 \text { October } 2017 \\
\text { Available Online: } \\
\text { 10 December } 2017\end{array}$ \\
\hline \hline
\end{tabular}

A field experiment was conducted during zaid season of 2016 at Crop Research Farm, Department of Agronomy, Naini Agricultural Institute, Sam Higginbottom University of Agriculture, Technology and Sciences, Allahabad (U.P.). The soil of experimental field was sandy loam having $\mathrm{pH}$ of 7.4 with $0.39 \%$ organic Carbon, available $\mathrm{N}, \mathrm{P}, \mathrm{K}$, as 185.5 , 36 and $98 \mathrm{~kg} \mathrm{ha}^{-1}$ respectively. The experiment was laid out in Randomized Block Design with twelve treatments each replicated thrice, comprising of two seed bed viz., $\mathrm{S}_{1}$ (flat bed at $45 \mathrm{~cm} \times 15 \mathrm{~cm}$ ) and $S_{2}$ (ridge and furrow at $45 \mathrm{~cm} \times 15 \mathrm{~cm}$ ) and three nitrogen levels $\left[\mathrm{N}_{1^{-}}\left(50 \%\right.\right.$ nitrogen through $\mathrm{FYM}+50 \%$ nitrogen through urea); $\mathrm{N}_{2^{-}}(50 \%$ nitrogen through poultry manure $+50 \%$ nitrogen through urea) and $\mathrm{N}_{3^{-}}(100 \%$ nitrogen through inorganic fertilizer)] and bio-fertilizer $\mathrm{B}_{1}$ (with Azospirillum) $\mathrm{B}_{2}$ (without Azospirillum). Results revealed that $S_{2}$ (Ridge and furrow) with nitrogen levels of $N_{3}(100 \%$ nitrogen through inorganic fertilizer) and $\mathrm{B}_{1}$ (with Azospirillum) recorded maximum grain yield (2.53 $\left.\mathrm{t} \mathrm{ha}^{-1}\right)$, stover yield (5.74 $\left.\mathrm{t} / \mathrm{ha}\right)$, and test weight (14.38 g) and was economically superior than other treatments giving maximum Gross return, Net return and BC ratio as (₹ 79300), (₹ 49490) and (2.66) respectively.

\section{Introduction}

Sorghum (Sorghum bicolor L.) is major source of food for millions of people in the semi-arid tropics. It is fourth most important cereal crop in world after wheat, rice and maize. It is a major dry land food grain crop Deshmukh et al., (2014), and has potential of adoption to adverse climatic conditions. However, it is inferior in quality due to low protein content and presence of hydrocyanic acid Singh et al., (2010). The use of agrochemicals causes the degradation of cultivable land and increasing agricultural pollution hence, creating unhealthy situation. In order to balance this situation organic farming may be a solution in which instead of using of chemicals, natural resources such as organic matters, manures and microbes are used. Organic farming system relies on largescale application of animal wastes, farm yard manure (FYM), poultry manure (PM), compost, crop residues and green manuring, etc. which are best substitute for harmful chemicals.

The application of phosphate solubilising cultures, nitrogen fixers (Azospirillum) and increases the process of decomposition, releasing nutrients at a faster rate which 
increases the nutrient uptake by plants. Hence, research efforts are required to find out the influence of combined use of farmyard manure, poultry manure, inorganic fertilizers and bio-fertilizers in satisfying the overall nutrient requirement of sorghum crop.

\section{Materials and Methods}

The experiment was carried out during Zaid season 2016 at Crop Research Farm, Department of Agronomy, Naini Agricultural Institute, Sam Higginbottom University of Agriculture, Technology and Sciences, Allahabad (U.P.), which is located at $25^{\circ} 24^{\prime}$ $42^{\prime \prime} \mathrm{N}$ latitude, $81^{\circ} 50^{\prime} 56^{\prime \prime} \mathrm{E}$ longitude and at an altitude of $98 \mathrm{~m}$ above the mean sea level. This area is situated on the right side of the river Yamuna. The soil of experimental field was sandy loam, $\mathrm{pH}$ of soil was 7.4 with $0.39 \%$ organic Carbon. The experiment involving hybrid sorghum was laid out in Randomized Block Design with twelve treatments each replicated thrice, comprising of two seed bed viz., $\mathrm{S}_{1}$ (flat bed at $45 \mathrm{~cm} \times 15$ $\mathrm{cm}$ ) and $\mathrm{S}_{2}$ (ridge and furrow at $45 \mathrm{~cm} \times 15$ $\mathrm{cm})$ and three nitrogen levels $\left[\mathrm{N}_{1}=(50 \%\right.$ nitrogen through $\mathrm{FYM}+50 \%$ nitrogen through urea); $\mathrm{N}_{2}(50 \%$ nitrogen through poultry manure $+50 \%$ nitrogen through urea) and $\mathrm{N}_{3}$ (100\% nitrogen through inorganic fertilizer)] and bio-fertilizer $\mathrm{B}_{1}$ (with Azospirillum) $\mathrm{B}_{2}$ (without Azospirillum). The variety used in the experiment was CSH-15.

\section{Results and Discussion}

\section{Growth characters}

Growth parameters of Sorghum, viz. plant height, dry weight crop growth rate, were significantly influenced by different seed bed and Integrated Nitrogen Management practices. Ridge and Furrow with $\mathrm{N}_{3}(100 \%$ nitrogen through inorganic fertilizer) and $\mathrm{B}_{1}$ (with Azospirillum) recorded maximum improvement in growth parameters, which were significantly superior to flatbed planting. The plant height of sorghum showed significant difference and highest plant height $(207.05 \mathrm{~cm})$ was recorded under treatment $\mathrm{T}_{11}$ [Ridge and furrow $+\mathrm{N}_{3}(100 \%$ nitrogen through inorganic fertilizer $+\mathrm{B}_{1}$ (with Azospirillum)] at 100 DAS followed by treatment $\mathrm{T}_{7}$ (Ridge and furrow $+50 \% \mathrm{~N}$ $\mathrm{FYM}+50 \% \mathrm{~N}$ through urea + with Azospirillum), which recorded plant height $(206.55 \mathrm{~cm})$ and was found to be at par to treatment $\mathrm{T}_{11}$

The probable reason for maximum plant height in treatment $T_{11}$ was due to the good rate of mineralization of nutrients. The other reason for higher plant height could be due to the fact that ridge and furrow sowing helps in maintaining the favorable moisture condition for relatively longer duration (Kantwa et al., 2006), and may also be due to increased availability of moisture as well as other factor like, aeration (Kshirsagar et al., 2014) (Table $1)$.

Similar findings have been reported by Rathore et al., (2006) and Tetarwal and Rana (2007). The dry weight of sorghum was significantly influenced by Seed bed and Integrated Nitrogen Management and the highest values was recorded in treatment $T_{11}$ which recorded $(132.30 \mathrm{~g})$ followed by $\mathrm{T}_{7}$ $(132.10 \mathrm{~g})$ at $100 \mathrm{DAS}$ respectively and was found to at par to treatment $\mathrm{T}_{11}$.

The probable reason for maximum dry weight in treatment $\mathrm{T}_{11}$ was due to the good rate of mineralization of nutrients and also because of taller plants. The other reason may be due to greater transfer of photosynthates from vegetative source to reproductive sink in this treatment. The maximum dry weight value under the ridge and furrow seed bed may be due to the better ambient environment for growth and development (Sharma et al., 2015). 
Table.1 Effect of seed bed and integrated nitrogen management on plant height, dry weight, and crop growth rate of sorghum (Sorghum bicolor L.)

\begin{tabular}{|c|c|c|c|c|}
\hline \multicolumn{2}{|c|}{ Treatments } & \multirow{2}{*}{$\begin{array}{c}\begin{array}{c}\text { Plant } \\
\text { height }(\mathbf{c m})\end{array} \\
186.93\end{array}$} & \multirow{2}{*}{$\begin{array}{c}\begin{array}{c}\text { Dry weight } \\
\text { (g) }\end{array} \\
115.80\end{array}$} & \multirow{2}{*}{$\begin{array}{c}\text { CGR (g/m } / \text { day) } \\
4.85\end{array}$} \\
\hline $\mathrm{T}_{1}$ & Flat bed $+50 \%$ N FYM + 50\% N Through urea + With Azospirillum & & & \\
\hline $\mathrm{T}_{2}$ & Flat bed + 50\% N FYM + 50\% N Through urea + Without Azospirillum & 176.50 & 110.76 & 3.77 \\
\hline $\mathrm{T}_{3}$ & Flat bed $+50 \%$ N Poultry manure $+50 \%$ N Through urea + With Azospirillum & 177.00 & 113.00 & 4.40 \\
\hline $\mathrm{T}_{4}$ & Flat bed $+50 \%$ N Poultry manure $+50 \% \mathrm{~N}$ Through urea + Without Azospirillum & 184.87 & 108.86 & 3.42 \\
\hline $\mathrm{T}_{5}$ & Flat bed $+100 \% \mathrm{~N}$ through inorganic fertilizer + With Azospirillum & 189.73 & 118.23 & 5.85 \\
\hline $\mathrm{T}_{6}$ & Flat bed $+100 \% \mathrm{~N}$ through inorganic fertilizer + Without Azospirillum & 176.53 & 122.10 & 5.37 \\
\hline $\mathrm{T}_{7}$ & Ridge and Furrow $+50 \%$ N FYM $+50 \%$ N Through urea + With Azospirillum & 206.55 & 132.10 & 6.01 \\
\hline $\mathrm{T}_{8}$ & Ridge and Furrow $+50 \%$ N FYM $+50 \%$ N Through urea + Without Azospirillum & 195.50 & 118.30 & 4.05 \\
\hline $\mathrm{T}_{9}$ & Ridge and Furrow $+50 \%$ N Poultry manure $+50 \%$ N Through urea + With Azospirillum & 200.51 & 127.80 & 5.60 \\
\hline $\mathrm{T}_{10}$ & Ridge and furrow $+50 \%$ N Poultry manure $+50 \% \mathrm{~N}$ Through urea + Without Azospirillum & 185.87 & 119.20 & 5.35 \\
\hline $\mathrm{T}_{11}$ & Ridge and Furrow $+100 \% \mathrm{~N}$ through inorganic fertilizer + With Azospirillum & 207.05 & 132.30 & 6.15 \\
\hline \multirow[t]{4}{*}{$\mathrm{T}_{12}$} & Ridge and Furrow $+100 \% \mathrm{~N}$ through inorganic fertilizer + Without Azospirillum & 197.67 & 125.10 & 5.52 \\
\hline & $\mathrm{F}-$ test & $\mathrm{S}$ & $\mathrm{S}$ & $\mathrm{S}$ \\
\hline & S. Ed. $( \pm)$ & 1.44 & 0.85 & 0.13 \\
\hline & C. D. at $5 \%$ & 2.98 & 1.75 & 0.27 \\
\hline
\end{tabular}

Table.2 Effect of seed bed and integrated nitrogen management on length of ear and test weight of sorghum (Sorghum bicolor L.)

\begin{tabular}{|c|c|c|c|}
\hline \multicolumn{2}{|r|}{ Treatments } & \multirow{2}{*}{$\begin{array}{c}\text { Length of ear }(\mathbf{c m}) \\
21.93\end{array}$} & \multirow{2}{*}{$\begin{array}{c}\text { Test weight }(\mathrm{g}) \\
10.76\end{array}$} \\
\hline $\mathrm{T}_{1}$ & Flat bed + 50\% N FYM + 50\% N Through urea + With Azospirillum & & \\
\hline $\mathrm{T}_{2}$ & Flat bed $+50 \%$ N FYM + 50\% N Through urea + Without Azospirillum & 20.20 & 9.02 \\
\hline $\mathrm{T}_{3}$ & Flat bed $+50 \%$ N Poultry manure $+50 \%$ N Through urea + With Azospirillum & 22.06 & 10.87 \\
\hline $\mathrm{T}_{4}$ & Flat bed $+50 \%$ N Poultry manure $+50 \% \mathrm{~N}$ Through urea + Without Azospirillum & 19.80 & 8.87 \\
\hline $\mathrm{T}_{5}$ & Flat bed $+100 \% \mathrm{~N}$ through inorganic fertilizer + With Azospirillum & 22.70 & 10.98 \\
\hline $\mathrm{T}_{6}$ & Flat bed $+100 \% \mathrm{~N}$ through inorganic fertilizer + Without Azospirillum & 22.33 & 9.36 \\
\hline $\mathrm{T}_{7}$ & Ridge and Furrow + 50\% N FYM + 50\% N Through urea + With Azospirillum & 25.70 & 12.92 \\
\hline $\mathrm{T}_{8}$ & Ridge and Furrow + 50\% N FYM + 50\% N Through urea + Without Azospirillum & 21.70 & 10.11 \\
\hline $\mathrm{T}_{9}$ & Ridge and Furrow $+50 \%$ N Poultry manure $+50 \% \mathrm{~N}$ Through urea + With Azospirillum & 23.86 & 11.62 \\
\hline $\mathrm{T}_{10}$ & Ridge and furrow $+50 \% \mathrm{~N}$ Poultry manure $+50 \% \mathrm{~N}$ Through urea + Without Azospirillum & 20.73 & 9.70 \\
\hline $\mathrm{T}_{11}$ & Ridge and Furrow $+100 \% \mathrm{~N}$ through inorganic fertilizer + With Azospirillum & 27.40 & 14.38 \\
\hline \multirow[t]{4}{*}{$\mathrm{T}_{12}$} & Ridge and Furrow $+100 \% \mathrm{~N}$ through inorganic fertilizer + Without Azospirillum & 21.83 & 10.31 \\
\hline & $\mathrm{F}-$ test & $\mathrm{S}$ & $\mathrm{S}$ \\
\hline & S. Ed. $( \pm)$ & 0.17 & 0.16 \\
\hline & C. D. at $5 \%$ & 0.36 & 0.34 \\
\hline
\end{tabular}


Table.3 Effect of seed bed and integrated nitrogen management on grain yield, stover yield, harvest index and protein content of sorghum (Sorghum bicolor L.)

\begin{tabular}{|c|c|c|c|c|c|}
\hline \multicolumn{2}{|c|}{ Treatments } & \multirow{2}{*}{$\begin{array}{c}\begin{array}{c}\text { Grain yield (t } \\
\left.\text { ha' }^{-1}\right)\end{array} \\
2.16\end{array}$} & \multirow{2}{*}{$\begin{array}{c}\begin{array}{c}\text { Stover yield } \\
\left.\text { (t ha }^{-1}\right)\end{array} \\
5.02\end{array}$} & \multirow{2}{*}{$\begin{array}{c}\begin{array}{c}\text { Harvest } \\
\text { index (\%) }\end{array} \\
30.08\end{array}$} & \multirow{2}{*}{$\begin{array}{c}\begin{array}{c}\text { Protein } \\
\text { content }(\%)\end{array} \\
10.17\end{array}$} \\
\hline $\mathrm{T}_{1}$ & Flat bed + 50\% N FYM + 50\% N Through urea + With Azospirillum & & & & \\
\hline $\mathrm{T}_{2}$ & Flat bed + 50\% N FYM + 50\% N Through urea + Without Azospirillum & 2.09 & 4.93 & 29.77 & 8.60 \\
\hline $\mathrm{T}_{3}$ & Flat bed $+50 \% \mathrm{~N}$ Poultry manure $+50 \% \mathrm{~N}$ Through urea + With Azospirillum & 2.22 & 5.10 & 30.32 & 10.01 \\
\hline $\mathrm{T}_{4}$ & Flat bed $+50 \%$ N Poultry manure $+50 \% \mathrm{~N}$ Through urea + Without Azospirillum & 2.17 & 5.09 & 29.88 & 8.70 \\
\hline $\mathrm{T}_{5}$ & Flat bed $+100 \% \mathrm{~N}$ through inorganic fertilizer + With Azospirillum & 2.27 & 5.40 & 29.59 & 10.37 \\
\hline $\mathrm{T}_{6}$ & Flat bed $+100 \% \mathrm{~N}$ through inorganic fertilizer + Without Azospirillum & 2.24 & 5.15 & 30.31 & 8.81 \\
\hline $\mathrm{T}_{7}$ & Ridge and Furrow $+50 \%$ N FYM $+50 \%$ N Through urea + With Azospirillum & 2.50 & 5.73 & 30.37 & 11.30 \\
\hline $\mathrm{T}_{8}$ & Ridge and Furrow + 50\% N FYM + 50\% N Through urea + Without Azospirillum & 2.34 & 5.40 & 30.23 & 9.47 \\
\hline $\mathrm{T}_{9}$ & Ridge and Furrow $+50 \%$ N Poultry manure $+50 \% \mathrm{~N}$ Through urea + With Azospirillum & 2.42 & 5.69 & 29.83 & 10.69 \\
\hline $\mathrm{T}_{10}$ & Ridge and furrow $+50 \% \mathrm{~N}$ Poultry manure $+50 \% \mathrm{~N}$ Through urea + Without Azospirillum & 2.29 & 5.30 & 30.17 & 9.37 \\
\hline $\mathrm{T}_{11}$ & Ridge and Furrow $+100 \% \mathrm{~N}$ through inorganic fertilizer + With Azospirillum & 2.53 & 5.74 & 30.59 & 12.02 \\
\hline \multirow[t]{4}{*}{$\mathrm{T}_{12}$} & Ridge and Furrow $+100 \% \mathrm{~N}$ through inorganic fertilizer + Without Azospirillum & 2.31 & 5.45 & 29.76 & 9.88 \\
\hline & $\mathrm{F}$ - test & $\mathrm{S}$ & $\mathrm{S}$ & $\mathrm{S}$ & $\mathrm{S}$ \\
\hline & S. Ed. ( $( \pm)$ & 0.04 & 0.08 & 0.09 & 0.17 \\
\hline & C. D. at $5 \%$ & 0.09 & 0.17 & 0.18 & 0.35 \\
\hline
\end{tabular}

Table.4 Effect of seed bed and integrated nitrogen management on cost of cultivation, gross return, net return and B: C ratio of sorghum (Sorghum bicolor L.)

\begin{tabular}{|c|c|c|c|c|c|}
\hline \multicolumn{2}{|c|}{ Treatments } & \multirow{2}{*}{$\begin{array}{c}\begin{array}{c}\text { Cost of } \\
\text { cultivation (₹/ha) }\end{array} \\
35735\end{array}$} & \multirow{2}{*}{$\begin{array}{c}\begin{array}{c}\text { Gross return } \\
\text { (₹/ha) }\end{array} \\
68300\end{array}$} & \multirow{2}{*}{$\begin{array}{c}\begin{array}{c}\text { Net return } \\
\text { (₹/ha) }\end{array} \\
32565\end{array}$} & \multirow{2}{*}{$\begin{array}{c}\text { B: } \mathbf{C} \\
\text { ratio }(\%) \\
1.91\end{array}$} \\
\hline $\mathrm{T}_{1}$ & Flat bed + 50\% N FYM + 50\% N Through urea + With Azospirillum & & & & \\
\hline $\mathrm{T}_{2}$ & Flat bed $+50 \%$ N FYM $+50 \%$ N Through urea + Without Azospirillum & 35535 & 66450 & 30915 & 1.86 \\
\hline $\mathrm{T}_{3}$ & Flat bed $+50 \%$ N Poultry manure $+50 \% \mathrm{~N}$ Through urea + With Azospirillum & 34855 & 69900 & 35045 & 2.00 \\
\hline $\mathrm{T}_{4}$ & Flat bed $+50 \% \mathrm{~N}$ Poultry manure $+50 \% \mathrm{~N}$ Through urea + Without Azospirillum & 34655 & 68850 & 34195 & 1.98 \\
\hline $\mathrm{T}_{5}$ & Flat bed $+100 \% \mathrm{~N}$ through inorganic fertilizer + With Azospirillum & 29810 & 72400 & 42590 & 2.42 \\
\hline $\mathrm{T}_{6}$ & Flat bed $+100 \% \mathrm{~N}$ through inorganic fertilizer + Without Azospirillum & 29610 & 71550 & 41940 & 2.41 \\
\hline $\mathrm{T}_{7}$ & Ridge and Furrow + 50\% N FYM + 50\% N Through urea + With Azospirillum & 35735 & 78650 & 42915 & 2.20 \\
\hline $\mathrm{T}_{8}$ & Ridge and Furrow $+50 \%$ N FYM $+50 \%$ N Through urea + Without Azospirillum & 35535 & 73800 & 38265 & 2.07 \\
\hline $\mathrm{T}_{9}$ & Ridge and Furrow $+50 \%$ N Poultry manure $+50 \% \mathrm{~N}$ Through urea + With Azospirillum & 34855 & 76850 & 41995 & 2.20 \\
\hline $\mathrm{T}_{10}$ & Ridge and furrow $+50 \% \mathrm{~N}$ Poultry manure $+50 \% \mathrm{~N}$ Through urea + Without Azospirillum & 34655 & 72300 & 37645 & 2.08 \\
\hline $\mathrm{T}_{11}$ & Ridge and Furrow $+100 \% \mathrm{~N}$ through inorganic fertilizer + With Azospirillum & 29810 & 79300 & 49490 & 2.66 \\
\hline $\mathrm{T}_{12}$ & Ridge and Furrow $+100 \% \mathrm{~N}$ through inorganic fertilizer + Without Azospirillum & 29610 & 73450 & 43840 & 2.48 \\
\hline
\end{tabular}

Market price of sorghum grain yield 20000 ₹/t; Market price of sorghum stover yield 5000 ₹/t 
As a result, the crop may have used water more efficiently with enhanced photosynthetic potential (Zhang et al., 2007). These findings are in accordance to that reported by Rathore and Gautam, (2003), Rathore et al., (2006) and Tetarwal and Rana (2007).

The crop growth rate was also differed significantly by seed bed and Integrated Nitrogen Management. The maximum CGR $\left(6.15 \mathrm{~g} / \mathrm{m}^{2} /\right.$ day) value was recorded in treatment $\mathrm{T}_{11}$ at 80-100 days interval followed by treatment $T_{7}$ which recorded CGR as (6.01 $\mathrm{g} / \mathrm{m}^{2} /$ day) and was found to be at par to treatment $\mathrm{T}_{11}$.

The probable reason for maximum crop growth rate in treatment $T_{11}$ was due to the good rate of mineralization of nutrients. The improvement in crop growth rate in the plots under ridge and furrow planting system may be due to the favorable air, temperature within crop canopy as well as reduced water stress (Chakravarti et al., 2010). Similar findings have been reported by Rathore et al., (2006).

\section{Yield and yield attributes of sorghum}

A perusal of the table 2 clearly shows that there was significant influence of seed bed and integrated nitrogen management on ear length of sorghum among different treatments. Maximum ear length $(27.40 \mathrm{~cm})$ was recorded in treatment $\mathrm{T}_{11}$ followed by treatment $\mathrm{T}_{7}$ which recorded ear length of $25.70 \mathrm{~cm}$. The table 2 also reveals that test weight also differed significantly among treatments and maximum value $(14.38 \mathrm{~g})$ was recorded in treatment $\mathrm{T}_{11}$ followed by treatment $\mathrm{T}_{7}$ which recorded test weight of $12.92 \mathrm{~g}$.

The probable reason for recording higher ear length and test weight in treatment $T_{11}$ may be due to the result of improvement in soil properties in terms of fertility, microbial abundance and other physical properties of soil which reflected on higher ear length and test weight. These finding are in collaboration with those reported by Naphade et al., (1990) and Raghuwanshi et al., (1998).

An appraisal of table 3 clearly shows that grain yield and stover yield was significantly influenced by seed bed and integrated nitrogen management among various treatments. The maximum grain yield $(2.53 \mathrm{t} / \mathrm{ha})$ was recorded in treatment $\mathrm{T}_{11}$ followed by treatment $T_{7}$ which recorded grain yield to a tune of (2.50 t/ha) and was found to be at par to treatment $\mathrm{T}_{11}$. Similarly, stover yield recorded maximum value in treatment $\mathrm{T}_{11}(5.74 \mathrm{t} / \mathrm{ha})$ followed by treatment $\mathrm{T}_{7}$ which recorded stover yield (5.73 $\left.\mathrm{t} / \mathrm{ha}\right)$ and was found to be at par to treatment $T_{11}$. Harvest index also differed significantly among treatments due to the influence of seed bed and integrated nitrogen management. The maximum harvest index value $(30.59 \%)$ was recorded in treatment $\mathrm{T}_{11}$ followed by treatment $\mathrm{T}_{7}$ which recorded harvest index as $(30.37 \%)$. Similarly, protein content was significantly influenced by seed bed and integrated nitrogen management. The maximum value $(12.02 \%)$ of protein content was recorded in treatment $\mathrm{T}_{11}$ followed by treatment $\mathrm{T}_{7}$ which recorded protein $\%$ as $11.30 \%$.

The probable reason for recording maximum grain yield, stover yield, harvest index and protein content might be due to better translocation of photosynthates from source to sink. The other reason may be due to better availability of nutrients which helped in continuous supply of nitrogen to the plants to maintain greenness of leaves for longer period which helped in greater dry matter accumulation which might have contributed to the development of sink and thereby increased the grain, stover yield, harvest 
index and protein \%. Painyuli et al., (2013), stated that the ridge and furrow planting method, gave higher growth, attributes mainly because of advantages of better aeration, least compaction, better seedling establishment, more nutrient uptake due to better root growth and also avoidance of water logging over flat planting. These results are in conformity with those reported by Dixit et al., (2005) and Khidrapure et al., (2015).

\section{Economics}

An appraisal of the table 4 clearly shows that maximum Gross return ( $₹$ 79300), net return (₹ 49490) and BC ratio (2.66) was recorded in treatment $T_{11}$ followed by treatment $T_{12}$ which recorded net return of (₹. 43840) and $\mathrm{BC}$ ratio 2.48. This may be due to higher grain yield and stover yield recorded in treatment $\mathrm{T}_{11}$ [Ridge and furrow $+\mathrm{N}_{3}(100 \%$ nitrogen through inorganic fertilizer $+\mathrm{B}_{1}$ (with Azospirillum)].

From the above findings, it can be concluded that for obtaining the maximum growth, yields and benefits from cultivation of sorghum, it should be sown by ridge and furrow method and $100 \%$ nitrogen should be provided through urea alone and seeds should be inoculated with Azospirillum culture before sowing. Although these findings are from one year experimentation, therefore it should be repeated to confirm the findings.

\section{References}

Chakravarti, A.K., Moitra, R., Mukherjee, A., Dev, P. and Chakraborty, P.K. 2010. Effect of planting methods and mulching on the thermal environment and biological productivity of groundnut. Journal of Agro Metrology, 12(1): 17-80.

Deshmukh, Ashwani, Sonune, B.A., Gabhane, V.V., and Rewatkar, S.S. 2014. Impact of Integrated Nutrient Management on soil fertility and yield of sorghum genotypes in vertisol. Agric. Sci. Digest., 34(2): 111-114.

Dixit, A.K, Singh, O.P, Dileep, K. and Amarjit, S.B., (2005). Response of promising rainy season Sorghum (Sorghum bicolor L.) genotypes to nitrogen and phosphorus fertilizers. Indian J. Agron., 50: 206 -20.

Kantwa, S.R., Ahlawat, I.P.S. and Gangaiah, B. 2006. Performance of sole and intercropped pigeonpea as influenced by land configuration, post-monsoon irrigation and phosphorus fertilization. Indian Journal of Agricultural Sciences, 76(10): 635-637.

Khidrapure, R.M, Kubsad, V.S, and priya, H.R, (2015). Effect of split application of nitrogen on biometric growth parameters, nitrogen use efficiency and yield of khrif Sorghum (Sorghum bicolor). Res. Enviran. Life Sci., 8 (2), 167- 170.

Kshirsagar, S.M., Pawar, H.V. and Wade, N.C. 2014. Studies on the response of sesame growth parameter to different planting systems, varieties and organic manures. Trends in Biosciences, 7(20): 3155-3159.

Naphade, P.S., Wankhede, S.G. and Mahajan, N.V. (1990). Response of hybrid sorghum to $\mathrm{Zn}$ and $\mathrm{Mn}$ application. P.K.V. Res. J., 14 (2): 185-187.

Painyuli, Amit, Pal, M.S., Bhatnagar, Amit, and Bisht, A.S. 2013. Effect of planting techniques and irrigation scheduling on productivity and water use efficiency of sweet corn. Indian Journal of Agronomy, 58(3): 344-348.

Raghuwanshi, R.S., Pawar, K.B. and Patil, J.D. (1998). Effect of bio-fertilizer and $\mathrm{N}$ levels on yield and nitrogen economy in pearl millet under dryland condition. Madras Agri. J., 184 (11/12): 556-558

Rathore, V.S., Singh, P. and Gautam, R.C. 
(2006). Productivity and Water use efficiency of rainfed pearlmillet (Pennisetum glaucum L.) as influenced by planting patterns and Integrated Nutrient Management. Indian J. Agron. 51(1): 46-48.

Sharma, Babloo, Kumari, Reena, Kumari, Pratibha, Meena, K.,Santosh and Singh R.M. 2015. Effect of planting pattern on productivity and water use efficiency of pearl millet in the semi-arid region. Journal of the Indian Society of Soil Science, 63(2): 259-265.

Singh, R.K., Chakraborthy, D. Garg, R.N., Sharma, P.K. and Sharmam U.C. (2010). Effect of different water regimes and $\mathrm{N}$ application on growth, yield, water use and nitrogen uptake by pearlmillet. Indian J. of Agri. Sci., 80 (3): 213-216.

Tetarwal, J.P. and Rana, K.S., (2007). Impact of cropping system fertility level and moisture conservation practice on productivity, nutrient uptake, water use and profitability of pearlmillet (Pennisetum glaucum L.) under rainfed conduction. Indian J. Agron. 51 (4): 263-266.

Zhang, J., Sun, J., Duan, A., Wang, J., Shen, X. and Liu, X. 2007. Effects of different planting patterns on water use and yield performance of winter wheat in the huang -huai- hai plain of China. Agricultural Water Management, 92: 41-47.

\section{How to cite this article:}

Ashwani Singh and Rajesh Singh. 2017. Effect of Seed Bed and Integrated Nitrogen Management on Growth and Yield of Sorghum (Sorghum bicolor L.). Int.J.Curr.Microbiol.App.Sci. 6(12): 401-407. doi: https://doi.org/10.20546/ijcmas.2017.612.048 